\title{
Tip 2 Diyabetes Mellitus Tanılı Hastalarda El Komplikasyonları ve Klinik Verilerle iliş̧kisi
}

Hand Complications and Its Relationship with Clinical Data in Patients with Type 2 Diabetes Mellitus Kemal Erol ${ }^{1}$ (D), Hatice Uğurlu

\section{özeT}

AMAÇ: Tip 2 Diyabetes Mellitusun (T2DM) kronik komplikasyonlarından biri el tutulumudur. Son yıllarda 'Diyabetik El' ile ilgili uluslararası mecrada artmış çalışmalara rağmen ülkemizde 'Diyabetik El' ile ilgili yayın sayısı azdır. Biz de bu çalışmada ülkemizde lç̧ Anadolu Bölgesi'nde üçüncü basamak bir sağlık merkezinin endokrinoloji polikliniğine başvuran T2DM tanılı hastalarda el bozukluklarının sıklığını belirlemeyi ve T2DM ilişkili klinik ve laboratuvar veriler ile arasındaki ilişkiyi araştırmayı amaçladık.

GEREÇ VE YÖNTEM: Çalışmaya üçüncü basamak bir sağlık merkezinin endokrinoloji polikliniğine başvuran T2DM tanısı almış olan, 18-65 yaş arası hastalar ardı sıra alındı. Elde bozukluğa yol açan başka hastalıkları olanlar çalışmaya alınmadı. Hastaların demografik ve DM ilişkili laboratuvar ve klinik verileri kaydedildi. Mikrovasküler ve makrovasküler komplikasyonlar, hastane bilgi sisteminden ve hastalardan alınan bilgilerden elde edildi. Hastaların el muayeneleri, hastaların DM ilişkili verilerine kör bir fiziksel tıp ve rehabilitasyon hekimi tarafından yapıldı ve diyabetik el tutulumu açısından değerlendirildi.

BULGULAR: Çalışmaya 86`sı (\%73.5) kadın 117 T2DM tanılı hasta alındı. Hastaların üçte ikisinde el şikayeti vardı ve yaklaşık dörtte üçünde en az bir el komplikasyonu tespit edildi. Hastalarda bulunan el komplikasyonlarının sıklık oranları şöyle idi; kısıtlı eklem hareketi sendromu: \%43.6; karpal tünel sendromu: \%54.7; Dupuytren kontraktürü: \%13.7; tetik parmak: \%7.7; sklerodaktili: \%32.5; ve kompleks bölgesel ağrı sendromu: \%1.7.

SONUÇ: T2DM'de sık görülen komplikasyonlardan olan el tutulumu lç Anadolu Bölgesi'nde üçüncü basamak bir hastanede takipli hastalarda yaklaşık olarak her 4 hastanın 3’ünde tespit edildi. T2DM tanılı hastalar değerlendirilirken el tutulumu açısından da değerlendirilmesi gereklidir.

Anahtar Kelimeler: diyabetik el, Dupuytren kontraktürü, karpal tünel sendromu, kısıtlı eklem hareketi sendromu, tetik parmak

\section{ABSTRACT}

OBJECTIVE: Hand involvement is one of the chronic complications of the type 2 diabetes mellitus (T2DM). Despite the increasing studies in international literatures about 'Diabetic Hand' in recent years, there are only a few studies on 'Diabetic Hand' in our country. We aimed in this study that, to determine the prevalence of hand disorders in patients with T2DM who admitted to a tertiary hospital's endocrinology outpatient clinic in Central Anatolian Region of Republic of Turkey, and to investigate relationship of hand disorders and diabetes related laboratory and clinic data.

MATERIALS AND METHODS: Patients with T2DM, 18-65 years old, who admitted to a tertiary hospital's endocrinology outpatient clinic in Central Anatolian Region of Republic of Turkey were enrolled in the study, consecutively. Patients who had other diseases lead to hand disorders were excluded. Patients' demographic, diabetes related clinic and laboratory data were recorded. The information about the patients' microvascular and macrovascular complications was obtained from hospital information system. Patients' hand examination was performed by a physiatrist who was blinded to patients' DM related data.

RESULTS: A total of 117 patients with T2DM, 86 of whom (73.5\%) were women, were included in the study. Two third of the patients had hand complaints. Almost three fourth of the patients had at least one hand disorder. Prevalence of the hand complications was as follows; limited joint mobility: 43.6\%; carpal tunnel syndrome: 54.7\%; Dupuytren's contracture: $13.7 \%$; trigger finger: $7.7 \%$; sclerodactyly: 32.5\%; and complex regional pain syndrome: $1.7 \%$.

CONCLUSION: Hand involvement, which is one of the common complications in T2DM, was detected in almost 3 of every 4 patients in the follow-up patients of a tertiary hospital in Central Anatolia Region. When evaluating patients with T2DM, hand involvement should also be evaluated.

Keywords: carpal tunnel syndrome, diabetic hand, Dupuytren's contracture, limited joint mobility syndrome, sclerodactyly, trigger finger

Yazışma Adresi/Address for Correspondence: Kemal Erol, MD, Kayseri Şehir Hastanesi, Şeker Mahallesi, Molu Caddesi, 38080 Kocasinan/ Kayseri/ Türkiye E-Posta/E-Mail: erolk.md@gmail.com || Tel: +90 3523157700 (iç hat: 20161)

Received/Geliş Tarihi: 20.07.2020 || Accepted/Kabul Tarihi: 06.08.2020

Bu Eser Creative Commons Atıf-Gayriticari 4.0 Uluslararası Lisansı İle Lisanslanmıştır. This work is licensed under a Creative Commons

Attribution-NonCommercial 4.0 International License (CC BY-NC 4.0). 


\section{GíRiş}

İnsülin salgılanmasında azalma ve/veya insülin etkisinde bozukluk sonucu gelişen hiperglisemi ile seyreden diyabetes mellitusta (DM), uzun süreli hiperglisemi kronik komplikasyonlara neden olur (1). Diyabetik hastalarda uzun süreli hipergliseminin hedeflerinden biri olan el dokularında gelişen bozuklukları tanımlamak için literatürde "Diyabetik El" terimi kullanılmaktadır (2). Karpal tünel sendromu (KTS), kısıtlı eklem hareketi sendromu (KEHS), tetik parmak (TP), Dupuytren kontraktürü (DK), kompleks bölgesel ağrı sendromu (KBAS), diyabetik el bozukluklarındandır (2). Bu bozukluklar genel popülasyonda da görülmekle birlikte "Diyabetik El" olarak adlandırılma sebepleri görülme sıklığı, hastalık seyri, tedavi yöntemleri ve tedaviye yanıtlarında diyabetik hastalarda bazı farklılıklar bulunmasıdır (2). Diyabetik el bozukluklarının öneminin asıl nedeni el fonksiyonlarında azalmaya yol açmalarıdır (3). İlk şikayet olarak el bozukluğu ile başvuran kimi hastalarda diyabet tanısına gidilmesi ve bazı diyabetik el bozukluklarının diğer organlardaki mikrovasküler komplikasyonları öngörmesi diyabetik el bozukluklarını tanımanın önemini artırmaktadır (4). Diyabetik el bozuklukları medikal, fiziksel ve/veya cerrahi tedaviye yanıt vermektedir ve tedavi ile hastaların yaşam kalitesi artmaktadır (1).

Son yıllarda 'Diyabetik El' ile ilgili uluslararası mecrada artmış çalışmalara rağmen ülkemizde 'Diyabetik El' ile ilgili yayın sayısı azdır. Biz de bu çalışmada ülkemiz iç̧ Anadolu Bölgesi'nde üçüncü basamak bir sağlık merkezinin endokrinoloji polikliniğine başvuran tip 2 DM tanılı hastalarda el bozukluklarının sıklığını belirlemeyi ve bu bozukluklar ile hastaların yaşı, cinsiyeti, vücut kitle indeksi (VKi), sigara kullanımı, diyabet süresi, HbA1c düzeyi, mikrovasküler ve makrovasküler komplikasyonlar arasındaki ilişkiyi araştırmayı amaçladık.

\section{GEREÇ VE YÖNTEM}

İç Anadolu Bölgesi'nde üçüncü basamak bir sağlık kuruluşunun endokrinoloji polikliniğine başvuran, tip 2 DM (T2DM) tanısı ile takipli olan ve çalışmaya katılmayı kabul eden 18-65 yaş arası hastalar, polikliniğe başvurma sırası ile çalışmaya dahil edildi. El bozukluğuna yol açan romatoid artrit gibi inflamatuvar romatizmal hastalığı olanlar, travmatik el yaralanması öyküsü olanlar, nörojenik el bozukluğu olanlar, son dönem böbrek yetmezliği olanlar ve siroz tanısı olan hastalar çalışmaya dahil edilmedi. Çalışmaya 117 T2DM tanılı hasta alındı.
Hastaların demografik verileri ile sigara kullanımı, alkol ve diğer alışkanlıkları, dominant eli, boyu, vücut ağırlığı, DM tanısının süresi, DM tedavisi için kullanmakta olduğu ilaçları, komorbid hastalıkları ve bu hastalıklar için kullanmakta olduğu ilaçlar kendilerine sorularak kaydedildi. Hastaların vücut-kitle indeksi (VKi); vücut ağırlıklarının, boylarının karesine bölünmesi ile hesaplandı.

Hastaların açlık kan glikozu ile HbA1c değerleri kaydedildi. Mikrovasküler komplikasyonlardan olan nefropati bulunup bulunmadığı spot idrar mikroalbumin/kreatinin oranı hesaplanarak tespit edildi. Retinopati varlığı, son 1 yıl içindeki göz muayene sonuçları hasta dosyalarından elde edilerek tespit edildi. Nöropati varlığını değerlendirmek için nöropatik semptom varlığı sorgulanıp duyu ve kas gücü muayenesi yapılarak; Dyck ve arkadaşlarının önerdikleri diyabetik sensörimotor polinöropati için minimal kriterlere göre belirlendi (5). DM'nin makrovasküler komplikasyonları olan koroner arter hastalığı $(\mathrm{KAH})$, serebrovasküler olay (SVO) ve periferik arter hastalı̆̆ $(\mathrm{PAH})$ varlığı hastalar sorgulanarak elde edildi.

Hastaların tümünün el muayenesi aynı fiziksel tıp ve rehabilitasyon hekimi tarafından (KE) yapıldı. Hastaların el şikayeti; ağrı, sabah tutukluğu, şişlik, eklemlerde kısıtlılık, kuvvetsizlik, uyuşma ve diğer şikayetler sorgulanarak kaydedildi. Palpasyonla elin ve parmakların palmar yüzlerinde nodül, pretendinöz bant, kontraktür, kalınlaşmış fleksör tendon, şişlik, terleme, Isı artışı, trofik değişiklik, parmakların dorsal yüzlerinde katılık varlığı tespit edildi. Yüzeyel dokunma duyusu muayenesi hastalarının ellerinin tenar bölgelerine $10 \mathrm{~g}$ mono filaman ile hassas olarak dokunma ile yapıldı. Phalen testi; hastanın her iki elini bilekten tam fleksiyona (90 derece) getirerek bu pozisyonda 60 saniye beklemesi istenerek yapıldı. Bu süre içinde elde median sinir duyusal dağılım alanında parestezi oluşması pozitif olarak kabul edildi. Tinel testi; bilek ön yüzünde karpal tünelin olduğu alan üzerine bir refleks çekici ile vurularak yapıldı ve elde median sinirin duyusal dağııım alanında parestezinin olması pozitif olarak kabul edildi. Median sinirin motor fonksiyonunu değerlendirmek için abduktor pollisis brevis ve opponens kas gücüne manuel olarak bakıldı. Sonuç 0 ile 5 arasında skorlandı. Hastaların her iki el bileği ekstansiyonda iken ellerinin palmar yüzlerini birbirine yapıştırması istendi ve ellerinin arasında boşluk kalırsa "Duacı eli" belirtisi pozitif olarak kabul edildi. Hastalardan ellerini masanın üzerinde düzleştirmesi istendi, 
masa ile elinin arasında boşluk kalırsa "Masa Üstü Testi" pozitif olarak kabul edildi.

KEHS tanısı, "Duacı eli" belirtisi ve "Masa üstü testi"nden en az birinin pozitif olması ile konuldu $(6,7)$. KTS tanısı, median sinir dağıım alanında ağıı veya parestezi veya duyu kaybı olması ve Tinnel veya Phalen testlerinden birinin varlığı veya şikayetlerin gece artması veya abduktor pollisis brevis kasında güçsüzlük olması durumunda klinik olarak konuldu $(6,7)$. DK tanısı, hastaların parmaklarında ağrısız katılık hissetmesi ve şu dört kriterden birinin bulunması ile konuldu; palmar veya dijital nodül bulunması, palmar veya dijital derinin gergin olması, pretendinöz bant bulunması ve parmak kontraktürü $(6,7)$. TP tanısı, parmağın fleksiyon ve ekstansiyon hareketi sırasında kilitlenme ile beraber nodül palpe edilmesi veya kalınlaşmış fleksör tendonun tespit edilmesi ile konuldu $(6,7)$. Sklerodaktili tanısı parmakların dorsal yüzlerindeki deri iki parmak arasında sıkıştırılarak kalınlaşma ve mum gibi katılaşma varlığında konuldu $(6,7)$. KBAS tanısı şu klinik bulguların varlığıyla konuldu; ağrı, vazomotor bulgular, sudomotor bulgular, trofik değişiklikler $(6,7)$.

\section{İstatistiksel Değerlendirme}

İstatiksel analizler SPSS (Statistical Package for Social Science) 16,0 paket programı ile yapıldı. Veriler ölçüm özelliğine göre, yüzde (\%), ortalama \pm standart sapma (SD) ve ortanca (çeyrekler arası aralık) olarak verildi. Bağımsız parametrik değişkenlerin karşılaştırılmasında Independent T-testi, non-parametrik değişkenlerin karşılaştırılmasında ise Mann-Whitney $U$ testi kullanıldı. Kategorik (dikotom) değişkenlerin karşılaştırılmasında ki-kare testi kullanıldı. P değeri $<0.05$ istatistiksel olarak anlamlı kabul edildi.

\section{BULGULAR}

Hastaların 31'i (\%26.5) erkek, 86'sı (\%73.5) kadın idi. Hastaların ortalama yaşı; $52 \pm 7.8$ (24-64), ortanca yaşı; 53 (47.5-58) idi. Hastaların diğer demografik verileri Tablo 1.de özetlenmiştir.

Hastaların VKi ortalaması; $30.8 \pm 5$ (15.9-41.2) iken, ortanca değeri; 30 (27.2-34.2) idi. Hastaların DM tanı süresi ortalama; $8.4 \pm 6.8$ (1-30) yıl idi. Hastaların HbA1C ortalaması; $8.5 \pm 2.3(5,2-15,6)$ iken, HbA1C ortanca değeri 7.9 (6.7-9.8) idi. 20 (\%17.1) hastada ise DM harici hastalık yoktu. Mikrovasküler ve makrovasküler komplikasyonların varlığı ile DM ilişkili klinik veriler Tablo 2.de özetlenmiştir.
Hastaların yapılan el muayeneleri sonucunda şu bulgular elde edildi; hastaların 76'sının (\%65) herhangi bir eli ile ilgili şikayeti vardı. Hastaların eli ile ilgili şikayetlerinin süresi ortalama; $3.65 \pm 3.4$ (1-15) yıl iken, ortanca değeri; 2.5 (1-5) yıl idi.

Tablo 1. Tip 2 DM tanılı hastaların demografik verileri

\begin{tabular}{|rlc|}
\hline & Gruplar & $\mathbf{n}(\%)$ / ortalama \pm s.s. \\
Cinsiyet, $\mathbf{n}$ (\%) & Erkek & $31(\% 26.5)$ \\
& Kadın & $86(\% 73.5)$ \\
Yaş & & $52 \pm 7.8$ \\
& Ev hanımı & $78(\% 66.7)$ \\
Meslek, $\mathbf{n}$ (\%) & Emekli & $11(\% 9.4)$ \\
& Profesyonel bir iş & $14(\% 12)$ \\
& İşçi & $14(\% 12)$ \\
Eğitim süresi; yıl & & $6.3 \pm 4.2$ \\
& Evli & $109(\% 93)$ \\
Medeni durum, $\mathbf{n}$ & Bekar & $2(\% 1.3)$ \\
(\%) & Dul & $6(\% 5.1)$ \\
& Sağ & $110(\% 94)$ \\
& Sol & $7(\% 6)$ \\
Dominant el, $\mathbf{n}$ (\%) & Var & $13(\% 11.1)$ \\
Sigara kullanımı, $\mathbf{n}$ & Bırakmış & $9(\% 7.7)$ \\
(\%) & Yok & $95(\% 81.2)$ \\
& Alkol kullanımı & $2(\% 1.7)$ \\
Diğer alışkanlıklar, & Aşırı çay tüketimi & $8(\% 6.8)$ \\
\hline & &
\end{tabular}

Tablo 2. Tip 2 DM tanılı hastaların diyabetle ilgili verileri

\begin{tabular}{|llc|}
\hline DM tanı süresi; yıl & Gruplar & $\begin{array}{c}\mathbf{n} \text { (\%) / ortalama } \\
\text { s.s. }\end{array}$ \\
HbA1c, ortalama s.s. & & $8.4 \pm 6.8$ \\
& & $8.5 \pm 2.3$ \\
Diyet, $\mathbf{n}$ (\%) & Düzenli & $45(\% 38.5)$ \\
& Düzensiz & $9(\% 7.7)$ \\
& Yapmayan & $63(\% 53.8)$ \\
Illaç kullanımı, $\mathbf{n}$ (\%) & OAD & $61(\% 52.1)$ \\
& İnsülin & $11(\% 9.4)$ \\
& OAD + İnülin & $40(\% 34.2)$ \\
& Kullanmayan & $5(\% 4.3)$ \\
& HT & $11(\% 9.4)$ \\
Komorbid hastalık, $\mathbf{n}$ & HT + Diğer & $18(\% 15.4)$ \\
(\%) & HL & $9(\% 7.7)$ \\
& HL + Diğer & $10(\% 8.5)$ \\
& HT + HL & $25(\% 21.4)$ \\
& HT + HL + Diğer & $10(\% 8.5)$ \\
Komorbid hastalık için & Diğer & $14(\% 12)$ \\
ilaç kullanımı, $\mathbf{n}$ (\%) & Yok & $20(\% 17.1)$ \\
Mikrovasküler & Yok & $87(\% 74.4)$ \\
komplikasyon, $\mathbf{n}$ (\%) & Nefropati & $30(\% 25.6$ \\
& Retinopati & $25(\% 21.6)$ \\
Makrovasküler & Nöropati & $22(\% 19)$ \\
komplikasyon, $\mathbf{n}$ (\%) & KAH & $64(\% 55.2)$ \\
& SVO & $17(\% 14.5)$ \\
& Diğer & $3(\% 2.6)$ \\
& & $8(\% 6.8)$ \\
\hline
\end{tabular}


DM: diyabetse mellitus; HL: hiperlipidemi; HT: hipertansiyon; $K A H$ : koroner arter hastalığl; OAD: oral antidiyabetik; SVO: serebrovasküler olay.

Eli ile ilgili şikayeti olan hastaların el şikayetinin başlangıç şekli; 9 (\%11.8) hastada ağrı, 3 (\%3.9) hastada sabah tutukluğu, 1 (\%1.3) hastada şişlik, 4 (\%5.3) hastada kuvvetsizlik, 56 (\%73.7) hastada uyuşma ve 3 (\%3.9) hastada başka şikayetler idi. El şikayeti bulunan ve bulunmayan hastalarda yaş, cinsiyet, sigara kullanımı, VKi, DM süresi, HbA1c değeri, nefropati sıklığı, retinopati sıklığı, nöropati sıklığı, KAH sıklığı benzerdi.

Tablo 3. Diyabetik El komplikasyonları ve sıklık yüzdeleri
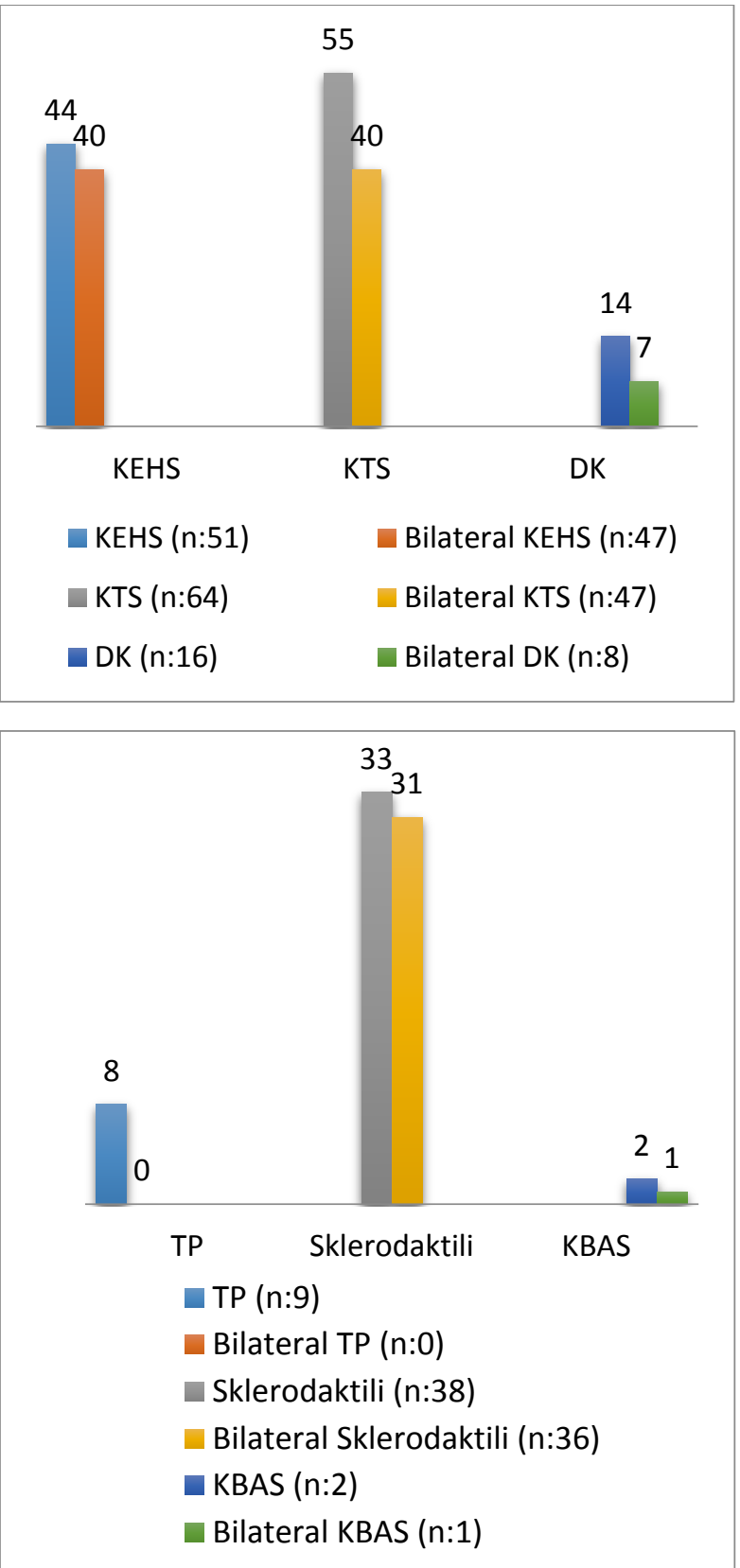

El komplikasyonu açısından değerlendirildiğinde bulgular şu şekilde idi; 51 hastada (\%43.6) KEHS, bunların 47'sinde (\%40.2) bilateral KEHS; 64 (\%54.7) hastada KTS, bunların 47'sinde (\%40.2) bilateral KTS; 16 hastada (\%13.7) DK, bunların 8'inde (\%6.8) bilateral DK; 38 (\%32.5) hastada sklerodaktili, bunların 36'sında (\%30.8) bilateral sklerodaktili; 2 (\%1.7) hastada KBAS, bunların 1'inde (\%0.9) bilateral KBAS; 9 (\%7.7) hastada TP vardı. Hiçbir hastada TP bilateral değildi. Toplamda hastaların 86'sında (\%73.5) diyabete bağıı en az bir el komplikasyonu vardı (Tablo 3).

Herhangi bir el komplikasyonu, KEHS, KTS, DK, TP, sklerodaktili var olanlar ve olmayanlar yaş, cinsiyet, VKi, sigara kullanımı, hastalık süresi, HbA1c değeri, nefropati, retinopati, nöropati, KAH varlığı açısından karşılaştırıldı. SVO geçiren hasta sayısı ve diğer makrovasküler komplikasyonları bulunan hasta sayısı istatistiksel analiz için yeterli değildi. İstatistiksel olarak anlamlı olan bulgular şu şekilde idi; KTS olan hastaların 56'sı (\%87.5) kadın ve 8'i (\%12.5) erkekti. Kadın hastalarda erkek hastalara göre KTS sıklığı daha fazla idi $(p<0.001)$. KTS olan hastaların 49'unda (\%77.8) nöropati de vardı. DM süresi, bilateral KTS bulunan hastalarda bulunmayanlara göre daha fazla idi $(p<0.05)$. DM süresi, KEHS bulunan hastalarda da bulunmayanlara göre daha fazla idi $(p<0.05)$. Bilateral KEHS bulunan hastaların 44'ü (\%93.6) kadın hasta iken 3'ü (\%6.4) erkek hasta idi. Bilateral KEHS olan hastaların büyük bir kısmı kadın cinsiyet idi $(p<0.001)$. Yine bilateral KEHS bulunan hastaların 38'inde (\%82.6) nöropati de vardı ve bilateral KEHS bulunanlarda, bulunmayanlara göre nöropati daha sık tespit edildi $(p<0.001)$. DK bulunan hastaların HbA1c ortalaması; 9.68 iken, DK bulunmayan hastaların HbA1c ortalaması; 8.3 idi $(p<0.05)$. TP bulunan hastaların HbA1c ortalaması 10.27 iken TP bulunmayan hastaların HbA1c ortalaması 8.34 idi $(p<0.05)$. TP bulunan hastaların VKi ortalaması; 27.66 iken, TP bulunmayan hastaların VKI ortalamasl; 31.07 idi $(p<0.05)$. Sklerodaktilisi bulunan 38 hastanın 28'inde (\%73.7) nöropati de vardı ve sklerodaktili bulunan hastalarda, bulunmayanlara göre nöropati daha sık tespit edildi $(p<0.05)$. Bilateral sklerodaktilisi bulunan 36 hastanın 27 'sinde (\%75) nöropati de vardı ve bilateral sklerodaktili bulunan hastalarda, bulunmayanlara göre nöropati daha sık tespit edildi $(p<0.05)$. Herhangi bir el komplikasyonu bulunan 86 hastanın 69'u (\%80.2) kadın hasta idi. El komplikasyonu bulunan hastaların çoğunluğu kadın idi $(p<0.05)$. Nöropati bulunan 64 hastanın 57'sinde (\%89.1) en 
az bir el komplikasyonu bulunuyordu $(p<0.05)$. Tüm karşılaştırmaların $p$ değerleri Tablo 4.'te verilmiştir.

Tablo 4. El komplikasyonu bulunan ve bulunmayan hastalarda demografik ve klinik verilerin karşılaştırılması sonucunda elde edilen ' $p$ ' değerleri

\begin{tabular}{|lcccccc|}
\hline & KEHS & $\begin{array}{c}\text { Bilateral } \\
\text { KEHS }\end{array}$ & KTS & $\begin{array}{c}\text { Bilateral } \\
\text { KTS }\end{array}$ & DK & $\begin{array}{c}\text { Bilateral } \\
\text { DK }\end{array}$ \\
Yaş & 0.67 & 0.90 & 0.21 & 0.38 & 0.48 & 0.11 \\
Cinsiyet & 0.67 & $\mathbf{0 . 0 0 *}$ & $\mathbf{0 . 0 0 *}$ & 0.10 & 0.55 & 0.10 \\
Sigara & 0.60 & 0.52 & 0.80 & 0.26 & 0.73 & 0.64 \\
VKi & 0.38 & 0.73 & 0.86 & 0.28 & 0.24 & 0.41 \\
DM süresi & $\mathbf{0 . 0 1}$ & 0.08 & 0.08 & $\mathbf{0 . 0 4 ^ { * }}$ & 0.20 & 0.43 \\
HbA1c & 0.17 & 0.48 & 0.50 & 0.18 & $\mathbf{0 . 0 2}$ & 0.82 \\
Nefropati & 0.46 & 0.51 & 0.16 & 0.87 & - & 0.68 \\
Retinopati & 0.68 & $\mathbf{0 . 0 1}$ & 0.09 & 0.84 & - & 0.64 \\
Nöropati & 0.10 & $\mathbf{0 . 0 0 *}$ & $\mathbf{0 . 0 0 *}$ & 0.24 & 0.72 & - \\
KAH & 0.56 & 0.72 & 0.92 & 0.72 & 0.25 & - \\
SVO & - & - & - & - & - & - \\
Diğer & 0.29 & - & 0.73 & - & 0.30 & 0.44 \\
\hline
\end{tabular}

\begin{tabular}{|c|c|c|c|c|}
\hline & TP & Sklerodaktili & $\begin{array}{c}\text { Bilateral } \\
\text { Sklerodaktili }\end{array}$ & El kompl. \\
\hline Yaş & 0.90 & 0.85 & 0.80 & 0.56 \\
\hline Cinsiyet & - & 0.79 & 0.99 & $0.01^{*}$ \\
\hline Sigara & 0.68 & 0.14 & 0.20 & 0.10 \\
\hline VKi & $0.04^{*}$ & 0.23 & 0.36 & 0.98 \\
\hline DM süresi & 0.70 & 0.09 & 0.18 & 0.15 \\
\hline HbA1c & $0.02^{*}$ & 0.26 & 0.36 & 0.50 \\
\hline Nefropati & 0.10 & 0.74 & 0.54 & 0.93 \\
\hline Retinopati & - & 0.34 & 0.39 & - \\
\hline Nöropati & 0.73 & $0.01^{*}$ & $0.01^{*}$ & $0.00^{*}$ \\
\hline KAH & - & 0.37 & 0.47 & - \\
\hline svo & - & - & - & - \\
\hline Diğer & - & - & - & - \\
\hline
\end{tabular}

KEHS: kısıtlı eklem hareketi sendromu, VKi: vücut kitle indeksi, DM: diyabetes mellitus, KAH: koroner arter hastalığı, SVO: serebrovasküler olay, El kompl.: El komplikasyonu ${ }^{p}<0.05$ olan istatistiksel olarak anlamlı değerler.

\section{TARTIŞMA}

iç Anadolu Bölgesi'nde tip 2 DM'de el komplikasyonlarını araştırdı̆̆ımız bu çalışmanın ana bulguları şunlardır; tip 2 DM tanılı hastaların üçte ikisinin eliyle ilgili bir şikayeti vardı. Hastaların dörtte üçünde diyabete bağlı el komplikasyonu tespit edildi. Hastaların yarıya yakınında KEHS, yarısında KTS, üçte birinde sklerodaktili mevcutken DK, TP ve KBAS daha az sıklıkta görüldü. KTS veya bilateral KEHS bulunanların çoğu kadın hasta iken, bilateral KTS bulunanlarda bulunmayanlara göre ve KEHS bulunanlarda bulunmayanlara göre DM süresi daha fazla idi. DK veya TP bulunan hastalarda bulunmayanlara göre HbA1c düzeyleri daha yüksekti. Bilateral KEHS bulunanlarda bulunmayanlara göre ve sklerodaktilisi olanlarda olmayanlara göre nöropati daha fazla tespit edildi.

Ardıç ve arkadaşlarının yapmış olduğu çalışmada hiçbir hastada KEHS tespit edilmemiş (8). Bu çalışmada KEHS bulunmamasının sebebi hastaların endokrinoloji veya iç hastalıkları polikliniğine başvuranlar değil de FTR polikliniğine başvuran hastalardan alınmış olması olabilir. Cederlund ve arkadaşları ise çalışmalarında KEHS sıklığını \%34,7 olarak bulmuşlar (9). Duyur Çakıt ve arkadaşları KEHS sıklığını \%67.5; Ramchurn ve arkadaşları \%36 olarak bulmuş $(10,11)$. Bazı derlemelerde tip 2 DM'lilerde KEHS sıklı̆̆ \%2576 olarak belirtilmiş ve cinsiyet, ırk ve HbA1c ile değerlendirilen metabolik kontrol ile ilişkili olmadığı ama DM süresi ve yaş ile ilişkili olduğu belirtilmiştir $(6,7)$. Bir başka derlemede ise tip 2 DM tanılı hastalarda KEHS sıklı̆̆ \% 45-76 olarak belirtilmiş ve KEHS bulunması ile yaş ve DM süresinin ilişkili olduğunu; KEHS bulunan hastalarda nefropati, retinopati daha sık görülmüş ve insülin kullanım sıklığının daha çok olduğu belirtilmiştir (12). Bizim çalışmamızda, tip 2 DM tanılı hastalarda KEHS sıklığı literatürdeki çalışmaların çoğu ile uyumlu iken biz KEHS bulunması ile cinsiyet, sigara kullanımı, nefropati, retinopati, nöropati, $\mathrm{KAH}$, diğer makrovasküler komplikasyonlar, yaş, HbA1c değeri ve VKi arasında anlamlı ilişki bulamadık. Ancak, KEHS bulunanlarda DM süresi daha fazla idi. Çalışmaların büyük çoğunluğunda bilateral KEHS bulunması araştırılmamıştı. Bizim çalışmamızda bilateral KEHS bulunan hastalarda bulunmayanlara göre kadın cinsiyet daha fazla idi. Yine, bilateral KEHS bulunan hastalarda bulunmayanlara göre nöropati daha fazla tespit edildi.

DM'de KTS prevalansı \%11-25 arasında ve kadınlarda daha sık olarak belirtilmektedir (13). Ayrıca KTS tanılı hastaların da \%5-8'inde DM olduğu söylenmektedir (14). Bir çalışmada da DM'nin unilateral KTS için değil de bilateral KTS için risk faktörü olduğu belirtilmiştir (15). Ardıç ve arkadaşları, DM tanılı hastalarda KTS sıklığını \% 1.3; Ramchurn ve arkadaşları ise \%25 olarak bulmuşlar $(8,11)$. Taşpınar, klinik olarak KTS tespit ettiği diyabetik hastalarda EMG çekmiş ve hastaların \% 59.09'unda KTS tanısını kesinleştirmiştir (16). Biz çalışmamızda klinik olarak KTS varlığına baktık ve hastaların hemen hemen yarısında klinik olarak KTS tespit ettik. KTS bulunma sıklığının bizim çalışmamızda diğer çalışmalara göre fazla olmasının sebebi KTS tanısının sadece klinik olarak konulmasıdır. Klinik olarak KTS tanısı 
konulan hastalara EMG yapılmamış olması çalışmamızın bir eksikliğidir. Comi ve arkadaşları diyabetik hastalarda KTS varlığının yaş ve DM süresi ile ilişkili olduğunu söylemişlerdir (17). Gamstedt ve arkadaşları KTS'nin DM süresi ile ilişkili olduğunu fakat metabolik kontrol, nefropati ve retinopati ile ilişkili olmadığını söylemişlerdir (18). Alp ve arkadaşları da KTS varlığı ile DM süresi arasında ilişki olduğunu söylemişlerdir (19). Biz ise çalışmamızda; hastalarda KTS bulunması ile yaş, DM süresi, sigara kullanımı, VKi, HbA1c değeri, nefropati, retinopati, KAH, diğer makrovasküler komplikasyonlar arasında anlamlı ilişki bulamadık. KTS bulunan hastalarda bulunmayanlara göre kadın cinsiyet daha fazla görüldü. Beklendiği gibi KTS bulunan hastalarda, KTS bulunmayan hastalara göre nöropati sıklığını daha fazla bulduk. Ayrıca bilateral KTS bulunan hastalarda bulunmayanlara göre DM süresi daha fazla idi.

DK, diyabetik hastaların \%16-42'sinde görülmektedir; yaş ve DM süresi arttıkça DK görülme sıklığı da artmaktadır $(18,20)$. Çeşitli çalışmalarda DK'nın uzun süreli kötü metabolik kontrol ve mikrovasküler komplikasyon varlığı ile ilişkili olduğu da belirtilmiştir (7). Bizim çalışmamızda; DK, 16 (\%13.7) hastada tespit edildi. 8 (\%6.8) hastada ise DK bilateraldi. DK bulunan hastaların $\mathrm{HbA1C}$ değerleri bulunmayanlara göre daha yüksekti. Ardıç ve arkadaşları (8) DK sıklığını \%21.8; Ramchurn ve arkadaşları ise \%17 olarak bulmuşlardır (11). Bizim çalışmamızda DK sıklı̆̆ı diğer çalışmalara göre azdır ve DM'de bildirilen oranların alt sınırına yakındır. Literatür ile uyumlu olarak kötü metabolik kontrolün DK ile ilişkili olduğunu tespit ettik fakat yaş ile ilişkisini tespit edemedik. Bu konu için daha fazla sayıda hasta ile çalışmalara ihtiyaç vardır.

TP, DM tanılı hastalarda \%10-15 sıklığında görülmektedir. Diyabet süresi, uzun süreli kötü metabolik kontrol ve mikrovasküler komplikasyon varlığı ile ilişkili olduğu söylenmektedir (7). Ramchurn ve ark. TP sıklığını tip 2 DM tanılı hastalarda \%38, Ardıç ve arkadaşları ise \%3.8 olarak bulmuşlardır $(8,11)$. Bizim çalışmamızda ise TP sıklığı \%7.7 idi ve hastaların hiçbirinde TP bilateral değildi. TP bulunan hastaların HbA1c değerleri, TP bulunmayan hastalara göre daha yüksekti. Literatürle uyumlu olarak kötü glisemi kontrolünü TP ile ilişkili bulduk fakat mikrovasküler komplikasyon varlığı ile TP ilişkisi tespit edemedik.

Parmakların daha çok dorsal yüzeylerinde katılaşma ile seyreden sklerodaktili sıklığının DM süresi arttıkça arttığı söylense de yeni diyabet tanısı konulmuş çocuk hastalarda da sklerodaktili görülebilmektedir (21). Biz çalışmamızda sklerodaktili sıklığını \%32.5 olarak bulduk ve hastaların \%30.8'inde sklerodaktili bilateraldi. Sklerodaktilisi bulunan 38 hastanın 28'inde (\%73.7) nöropati de vardı ve sklerodaktili bulunan hastalarda, bulunmayanlara göre nöropati daha sık tespit edildi. Yine, bilateral sklerodaktilisi bulunan hastalarda da bulunmayanlara göre nöropatiyi daha sık tespit ettik.

Genel toplumda KBAS sıklığı ile ilgili yeterli veri yoktur. Çalışmamızda tip 2 DM tanılı hastalarda KBAS'ı sadece 2 (\%1.7) hastada tespit ettik.

Çalışmaya üçüncü basmak endokrinoloji polikliniğine başvuran hastalar dahil edildiği için genel DM popülasyonundan klinik olarak daha ağır DM tanılı hastalar alınmış olması, KTS tanısının sadece klinik olarak konulmuş olması, retinopati varlığının retrospektif olarak hastane dosya sisteminden taranarak elde edilmesi çalışmanın temel kısıtıııklarıdır.

Sonuç olarak, tip 2 diyabette sık görülen komplikasyonlardan olan el tutulumu iç Anadolu Bölgesi'nde üçüncü basamak bir hastanede takipli hastalarda yaklaşık olarak her 4 hastanın 3'ünde tespit edildi. Dolayısıyla, Tip 2 DM tanılı hastalar değerlendirilirken el tutulumu açısından da değerlendirilmesi gereklidir.

Etik: Bu çalışmanın etik kurulu alınmıştır.

Ethics committee approval had been taken.

Yazar katkı durumu; Çalışmanın konsepti; KE, HU, dizaynı; KE, $\mathrm{HU}$, Literatür taraması; KE, HU, verilerin toplanması ve işlenmesi; KE, $\mathrm{HU}$, istatistik; KE, $\mathrm{HU}$, yazım aşaması; KE, $\mathrm{HU}$,

Author contribution status; The concept of the study; KE, HU, design; KE, HU, literature review; KE, HU, collecting and processing data; $\mathrm{KE}, \mathrm{HU}$, statistics; $\mathrm{KE}, \mathrm{HU}$, writing phase; $\mathrm{KE}$, $\mathrm{HU}$,

Yazarlar arasında çıkar çatışması yoktur.

The author declares no conflict of interest.

Finansal Destek: yoktur / Funding: none

doi: https://doi.org/10.33713/egetbd.769896

\section{KAYNAKLAR}

1. American Diabetes Association. Standards of medical care in diabetes-2017. Diabetes Care. 2017;40:11-24. 
2. Zyluk A, Puchalski P. Hand disorders associated with diabetes: a review. Acta Orthop Belg. 2015;81:191-196.

3. Savaş S, Köroğlu BK, Koyuncuoğlu HR, Uzar E, Celik H, Tamer NM. The effects of the diabetes related soft tissue hand lesions and the reduced hand strength on functional disability of hand in type 2 diabetic patients. Diabetes Res Clin Pract. 2007;77(1):77-83.

4. Hou WH, Li CY, Chen LH, et al. Medical claims-based casecontrol study of temporal relationship between clinical visits for hand syndromes and subsequent diabetes diagnosis: implications for identifying patients with undiagnosed type 2 diabetes mellitus. BMJ Open. 2016;6(10):e012071.

5. Dyck PJ, Albers JW, Andersen $H$, et al. Diabetic polyneuropathies: update on research definition, diagnostic criteria and estimation of severity. Diabetes Metab Res Rev. 2011; 27: 620-628.

6. Arkkila PET, Gautier JF. Musculoskeletal disorders in diabetes mellitus: an update. Best Pract Res Clin Rheumatol. 2003;17:945-970.

7. Kirazlı Y. Diyabetik El Rehabilitasyonu. FTR Bil Der. 2011:14 Özel Sayı;7-11.

8. Ardic F, Soyupek F, Kahraman Y, Yorgancıoğlu R. The musculoskeletal complications seen in type II diabetics: predominance of hand involvement. Clin Rheumatol. 2003;22: 229-233.

9. Cederlund RI, Thomsen N, Thrainsdottir S, Eriksson KF, Sundkvist G, Dahlin LB. Hand disorders, hand function, and activities of Daily living in elderly men with type 2 diabetes. J Diabetes Complications 2009;23:32-9.

10. Duyur Çakıt B, Özeri Z, Saraçoğlu M, Erdem HR. Diyabetes Mellituslu Hastalarda El ve Omuzu İlgilendiren Kas-ískelet Sistemi Komplikasyonları ve El Fonksiyonlarının Değerlendirilmesi. FTR Bil Der. 2009;12:99-103.

11. Ramchurn N, Mashamba C, Leitch E, et al. Upper limb musculoskeletal abnormalities and poor metabolic control in diabetes. Eur J Intern Med 2009; 20:718.

12. Lebiedz-Odrbina $D$, Kay J. Rheumatic Manifestations of Diabetes Mellitus. Rheum Dis Clin N Am 2010;36:681-699.

13. Chammas $M$, Bousquet $P$, Renard $E$, Poirier JL, Jaffiol $C$ \& Allieu Y. Dupuytren's disease, carpal tunnel syndrome, trigger finger and diabetes mellitus. Journal of Hand Surgery, 20A:1995;109-114.

14. Comi G, Lozza L, Galardi G, et al. Prevalence of carpal tunnel syndrome in diabetics: Effects of age, sex diabetes duration and polyneuropathy. Acta Diabetologica Latina, 22:1985;259-262.

15. Becker J, Nora DB, Gomes I, et al. An evaluation of gender, obesity, age and diabetes mellitus as risk factors for carpal tunnel syndrome. Clin Neurophysiol. 2002;113(9):1429-34.

16. Taşpınar Ş. Diyabetik Karpal Tünel Sendromunda Kortikosteroid Enjeksiyonu, Gece Ateli ve Fizik Tedavinin Etkinliğinin Karşılaştırılması (Uzmanlık Tezi). İstanbul:2005.

17. Comi G, Lozza L, Galardi G, et al. Prevalence of carpal tunnel syndrome in diabetics: Effects of age, sex diabetes duration and polyneuropathy. Acta Diabetologica Latina. 22:1985;259-262.
18. Gamstedt A, Holm-Glad J, Ohlson CG \& Sundstrom M. Hand abnormalities are strongly associated with the duration of diabetes mellitus. Journal of Internal Medicine. 1993;234,189-193.

19. Alp R, Türk Börü Ü, Sargın H. Tip 2 Diyabetlilerde Semptomatik Karpal Tünel Sendromu. Turkish J. Endocrinology and Metabolism. Vol. 7, No. 1, 2003.

20. Noble J, Heathcote JG \& Cohen H. Diabetes mellitus in the aetiology of Dupuytren's disease. Journal of Bone and Joint Surgery (Br) 1984; 66: 322-325.

21. Seibold JR. Digital sclerosis in children with insulindependent diabetes mellitus. Arthritis Rheum. 1982; 25:1357 